\title{
Using parasitoid wasps in Integrated Pest Management in museums against biscuit beetle (Stegobium paniceum) and webbing clothes moth (Tineola bisselliella)
}

\begin{abstract}
Biscuit beetle (Stegobium paniceum) and webbing clothes moth (Tineola bisselliella) cause much damage to museum objects. Some objects and materials are very attractive to these two pest species and objects are often re-infested after treatment. For some years parasitoid wasps have been used in biological pest control to treat and reduce infestations of stored product pests in food processing facilities. Their application in museums is still new and in a research stage. Results from five different museums in Germany and Austria and their application are presented. Lariophagus distinguendus wasps were released against Stegobium paniceum in the municipal library Augsburger Stadtarchiv (Germany), the Ethnological Museum in Berlin (Germany) and the Picture Gallery in the Kunsthistorisches Museum in Vienna (Austria). Trichogramma evanescens were released against Tineola bisselliella in the Technisches Museum in Vienna (Austria) and in the Deutsches Museum Verkehrszentrum in Munich (Germany). Results show that for active biscuit beetle infestations good results can be expected using the Lariophagus distinguendus in museums. Active clothes moth infestations are harder to treat but with a very regular and long-term exposure to the wasps, the clothes moth population can be reduced over the years. We see the application of parasitoid wasps as part of an Integrated Pest Management concept that should be used besides regular insect monitoring and other preventive measures. Difficulties, limitations and research needs in the application of parasitoid wasps in museums are discussed.
\end{abstract}

Key words: biological pest control, pest infestation, library, ethnological museum, pictures, historic vehicles, Lariophagus distinguendus, Trichogramma evanescens.

\section{INTRODUCTION}

An important part of Integrated Pest Management (IPM) in museums is the prevention of an insect attack. Different measures like sealing the building, regulating the climate, quarantine for all incoming objects, good cleaning and house keeping, training museum staff and monitoring all help to prevent an infestation (see for example Brokerhof, 2007; Kingsley et al., 2001; Pinniger, 2004; 2008; Pinniger \& Winsor, 2004; Querner \& Morelli, 2010a,b) and are all part of an IPM concept and of preventive conservation. If an infestation is still found in the collection, different treatment meth- 
ods like anoxia (nitrogen, argon or carbon dioxide), heating or freezing are applied in museums to kill the insects in all stages. Pesticides chemicals are normally not applied in museums anymore.

In recent years parasitoid wasps have been used in biological pest control to reduce infestations in food storage and processing facilities. Different parasitoid species are now commercially available and can be used against different moths and beetles. The results from different experiments of food selection, breeding parasitoids and releasing them against different stored product pests show good results. Publications are partly in German, see for example Schöller (1998a, b; 2010), Schöller \& Flinn (2000), Schöller \& Prozell (2003; 2006), Schöller et al. (1997; 2006), Hassan (1993) and Prozell et al. (1995). Their application in the food storage industry increases steadily in Europe (Zimmermann, 2004). As the same pests, such as biscuit beetles, tobacco beetles or webbing clothes moths, are also museum pests, parasitoids could also be used here. As yet few publications describe their use specifically in museums and libraries (but see Biebl 2009, Schöller 2010, Wilamowski et al., 2008).

The use of different species of parasitoids like Trichogramma evanescens Westwood, 1833, T. piceum Dyurich, 1987 or T. brassicae Bezdenko, 1968 against Tineola bisselliella was described and discussed by Adler \& Wudtke (1998), Biebl (2009), Plarre (2002), Plarre \& Balnuweit (2002) Plarre et al. (1999; 2000), Wudtke (2002), Zimmermann $(2005 ; 2004)$ and Zimmermann et al. (2003). Lariophagus distinguendus wasps were used against Stegobium paniceum in a historic library in Halle / Saale (Germany), where besides the book covers also the wheat straw insulation under the floorboards was infested (Schöller, 2010). Three other beetles regularly occurring in museums are also parasitized by Lariophagus distinguendus. These are the tobacco beetle Lasioderma serricorne (Fabricius, 1792) (see Steidle et al., 2006), the hump beetle Gibbium psylloides (Czenpinski, 1778) and the golden spider beetle Niptus hololeucus (Faldermann, 1836), described in Kassel (2008). Paul et al. (2007) discuss different parasitoid species used against common furniture beetles Anobium punctatum (DeGeer, 1774) but they seem much harder to treat using wasps. Wilamowski et al. (2008) present results from an infested library in Israel where Lariophagus distinguen$d u s$ were successfully used against Anobium punctatum, but Steidle et al. (2007) found L. distinguendus unsuitable against the common furniture beetle.

We tested the application of two parasitoid wasp species against Stegobium paniceum and Tineola bisselliella in five different museums. Both pests cause much damage to museum objects. Some materials and objects are very attractive to these two species and are often re-infested after treatment. Both have a world-wide distribution and are very common in cities, where they also occur in private homes or are pests on stored products.

\section{MATERIALS, METHODS AND RESULTS}

Parasitoid wasps were released in five separate collections in Germany and Austria with an active biscuit beetle (Stegobium paniceum) or webbing clothes moth (Tineola 
bisselliella) infestation. The release of the wasps was part of an IPM program in the museums to reduce or eradicate the pests. All parasitoid wasps were ordered from the company Biologische Beratung Ltd. (BIP) in Berlin.

\section{Augsburger Stadtarchiv, Germany}

In the large municipal library Augsburger Stadtarchiv an active Stegobium paniceum infestation was discovered in 2009. Besides cooling the rooms to slow down their development and treating the books with anoxia (nitrogen), 20 x 30 Lariophagus distinguendus wasps were released on two occasions in 2009 (August and September).

\section{Ethnological Museum Berlin, Germany}

In two collections (American and African Ethnology) of the Ethnological Museum in Berlin an active Stegobium paniceum infestation was discovered during insect monitoring in spring 2010. The monitoring was part of an IPM project (Querner \& Simon, submitted) in the foundation "Stiftung Preußischer Kulturbesitz". Different types of objects were infested in various collections such as basketry, voodoo dolls, pumpkin bowls or other objects made of plant material. As the monitoring with pheromone traps for biscuit beetles was not successful (the commercial traps did not capture any beetles, even though live and dead beetles were regularly found on the window sills) and a very large number of objects were possibly infested (over 100,000 objects in total), we decided to release 100 x 30 Lariophagus distinguendus wasps on three occasions in 2010 (July, August and September) in the two infested collections (both collections were connected by a large shaft). The wasps were released in the two large storage rooms and 36 individual closets with possibly infested objects. Besides this biological pest control, objects were treated with freezing and nitrogen.

\section{Picture Gallery in the Kunsthistorisches Museum Wien, Austria}

The large picture collection of the Kunsthistorisches Museum is stored in different depots. Pictures have been repeatedly infested by biscuit beetles (Stegobium paniceum) in the past and many pictures in the collection show historic or recent damage by them. They attack specifically the paintings lined with starch paste linings (also described in France by Fohrer et al., 2006). In 2010 a new outbreak of biscuit beetles was found in two of the large storage rooms during the monitoring. As the whole collection will be moved in 2011 to a new storage site, the pictures were not immediately treated. To reduce the beetle population and the damage to the paintings, we released $12 \times 30$ Lariophagus distinguendus individuals on three occasions in 2010 (April, May, June). The storage rooms were also cleaned and the number of sticky blunder traps increased. In 2011 no live or dead biscuit beetles were found on the objects, monitoring traps or floor of the storage rooms.

\section{Technisches Museum Wien, Austria}

One historic automobile in the museum exhibition space and one historic horse carriage in the storage depot of the museum were both heavily infested by webbing clothes 
moths for many years. Therefore in 2009 we performed a mass release of Trichogram$m a$ evanescens in both objects. Four cards with 2,000 wasps each were placed in the car and in the horse carriage every four weeks from May until August. During the whole time the monitoring with pheromone traps was continued to evaluate the effect of the parasitoids. The release of the wasps did not have any effect on the moth catch during the whole active period of the moths.

\section{Deutsches Museum Verkehrszentrum München, Germany}

Felt mats in the historic cars in museum exhibition rooms were repeatedly infested with webbing clothes moths in the Deutsches Museum Verkehrszentrum in Munich. Trichogramma evanescens were released on a weekly basis in 74 cars and vehicles with a total number of 45,000 individuals per year. With the help of pheromone traps, the moth populations were monitored during the parasitoid release (2007-2009). After the third year of the release a significant decrease of moths was found from an average of 10-15 moths per car down to 2-3 moths per car. In some cars the moths were completely exterminated. Besides the release of the wasps and the monitoring, individual cars were treated with freezing, heat or nitrogen against the infestations.

\section{DISCUSSION}

We could show that the use of parasitoid wasps as part of an Integrated Pest Management concept in museums might have a big future. The method is cheap, easy to use and two of the main museum pests can be treated in a very effective way. Especially for objects that cannot be transported to a nitrogen chamber parasitoid wasps can do a good job in reducing the pest population or eradicating them altogether. We see using parasitoids as a part of an overall Integrated Pest Management concept in the museum. Only if other measures are also taken, like sealing the building, regular cleaning and introducing a quarantine, can new infestations in the collection be prevented. The temperature in the collection is an important aspect that has to be considered; parasitoid wasps are only active and able to find the eggs and larvae of the pests with temperatures above $15^{\circ} \mathrm{C}$. In the museums mentioned most objects were still treated with nitrogen or freezing to kill the pests but more research could prove the release of parasitoids is also a suitable biological pest management or a preventive management strategy for museums with a regular release of wasps like in the Deutsches Museum Verkehrszentrum in Munich where they are still being released. The lack of effect found in the Technisches Museum in Vienna might be the very small size of Trichogramma evanescens wasps and their difficulty in getting to the moth larvae in the horsehair stuffing in the cars or carriages.

Still more research is needed to evaluate the efficiency of parasitoid wasps for their use in museums and to breed and test more parasitoid species for the different pests occurring in museums. Conservators of the collections are often not happy with the idea of releasing a large number of small insects in their storage rooms, so the effect of the parasitoid wasp has to be explained to them, and cleaning the collection after 
treatment to eliminate the dead insects (pests and parasitoids) is also important. For the moment, their use is limited to the parasite species commercially available. Future research should focus on common species of museum pests like Anobium punctatum or different Anthrenus, Attagenus or Dermestes species, as they cause much damage on museum objects, especially in ethnological and natural history collections.

\section{ACKNOWLEDGEMENTS}

We thank the different museums for supporting and funding an IPM program and for their openness to testing and funding the use of parasitoid wasps in their collections. We also thank all the conservators we have worked with for their part in the IPM program

\section{REFERENCES}

Adler C., Wudtke A., 1998 - Zur Wirksamkeit des Eiparasitoiden Trichogramma evanescens Westwood bei der Bekämpfung der Kleidermotte Tineola bisselliella (Hummel). 51. Dt. Pflanzenschutztagung Halle, Mitt. Biol. Bundesanstalt für Land- und Forstwirtschaft, 357: 332-333.

BIEBL S., 2009 - Deutsches Museum: Nützlinge gegen Kleidermotten. Der praktische Schädlings Bekämpfer, 3: 14-15.

Brokerhof A.W., van Zanen B., van de Watering K., Porck H., 2007 - Buggy Biz: Integrated Pest Management in Collections, In: Netherlands Institute for Cultural Heritage (ICN), Amsterdam.

Fohrer F., Baslé K., Daniel F., 2006 - Problématique de l'infestation des colles de rentoilage des peintures de chevalet par le Stegobium paniceum (L.), Support tracé, 6: 78-85.

HASSAN S.A., 1993 - The mass rearing and utilization of Trichogramma to control lepidopterous pests: Achievements and outlook. Pesticide Sci., 37: 387-391.

Kassel A., 2008 - Im Würgegriff. Biologische Schädlingsbekämpfung bei Messingkäfer- und Kugelkäfer-Befall. B+B Bauen im Bestand, 31: 42-43.

Kingsley H., Pinniger D., Xavier-Rowe A., Winsor P., 2001 - Integrated Pest Management for Collections, In: Proceedings of 2001: A Pest Odyssey, James \& James, London.

Paul F., Prozell S., Schöller M., 2007 - Monitoring natürlicher Feinde des Gemeinen Nagekäfers Anobium punctatum (DeGeer, 1774) (Coleoptera: Anobiidae). Mitteilungen der Deutschen Gesellschaft für Allgemeine und Angewandte Entomologie, 16: 323-326.

Pinniger D.B., 2004 - Pest Management in Museums, Archives and Historic Houses, Archetype Publications, London.

Pinniger D.B., 2008 - Pest Management a practical guide. Collection Trust, Cambridge.

Pinniger D.B., Winsor P., 2004 - Integrated pest management. A guide for museums, libraries and archives. Museum Libraries Archives.

Plarre R., Lieber K., Burkholder W., Phillips J., 1999 - Host and host instar preference of $A$ panteles carpatus (Say) (Hymenoptera: Braconidae) a possible parasitoid for biological control of clothes moths (Lepidoptera: Tineidae). Journal of Stored Products Research, 35: 197-213. 
Plarre R., Reichmuth F., 2000 - Impact. In: Subramanyam B., Hagstrum D.W., (Eds) - Alternatives to Pesticides in Stored-Product IPM. Kluwer Academic Publishers, Boston, USA: 401417.

Plarre R., Lieber K., Burkholder W., 2000 - Semaphorontenpräferenz von Apanteles carpatus (SAY) (Hymenoptera: Braconidae). Eine Parasitoide von Tineola bisselliella (Hummel) (Lepidoptera: Tineidae). Mitt. Dtsch. Ges. Ent., 12: 499-504.

Plarre R., 2002 - Parasitierungsbiologie von Apanteles carpatus (Hymenoptera: Braconidae), eines Parasitoiden an Textilmotten (Lepidoptera: Tineidae). DGaaE Nachrichten, 16 (1): 11.

Plarre R., Balnuweito O., 2002 - Biology of Apanteles carpatus (Hymenoptera: Braconidae), a parasitoid of tineid moths (Lepidoptera: Tineidae). In Advances in stored product protection. Proceedings of the $8^{\text {th }}$ International Working Conference on Stored Product Protection, York, UK, 22-26 July 2002: 169-172.

Prozell S., Schöller M., Reichmuth C., Wührer B., Hassan S., 1995 - Akzeptanz von Trichogramma-Freilassungen im Einzelhandel - Monitoring und Erfolgskontrolle. DGaaE-Nachrichten, 9: 121.

Querner P., Morelli M., 2010a - Integrierte Schädlingsbekämfung in Museen - Erfahrungen einer Umstellung. Restauro, Fachzeitschrift für Kunsttechniken, Restaurierung und Museumsfragen, 4: 234-241.

Querner P., Morelli M., 2010b - Leitfaden für eine Einführung und Umstellung zur Integrierten Schädlingsbekämpfung (IPM). Restauro, Fachzeitschrift für Kunsttechniken, Restaurierung und Museumsfragen, 5: 332-333.

Querner P., Simon S., (submitted) - Developing and implementing an Integrated Pest Management concept in the large collections of the National Museums in Berlin.

SCHÖLLER M., 1998a - Integration of biological and non-biological methods for controlling arthropods infesting stored products. Postharvest News and Information, 9: 15N-20N.

SCHÖLLER M., 1998b - Biologische Bekämpfung vorratsschädlicher Arthropoden mit Räubern und Parasitoiden - Sammelbericht und Bibliographie. . Mitt. Bio. Bundesanst. Land. Forstwirtsch., 342: 85-191.

SCHÖLLER M., 2010 - Biological control of stored-product insects in commodities, food processing facilities and Museums. 10th International Working Conference on Stored Product Protection Julius-Kühn-Archiv., 425: 596-606.

Schöller M., FlinN P.W., 2000 - Parasitoids and predators. In: Subramanyam B., Hagstrum D.W., (Eds) - Alternatives to Pesticides in Stored Product IPM. Kluwer Academic Publishers, Boston, USA: 229-271.

Schöller M., Prozell S., 2003 - Five years of biological control of stored-product moths in Germany. In Advances in stored product protection. Proceedings of the 8th International Working Conference on Stored Product Protection, York, UK, 22-26 July, 2002: 322-324.

Schöller, M., Prozell, S., 2006 - Natural enemies to control stored product pests in grain stores and retail stores. In: Stengård Hansen L., Enkegaard A., Steenberg T., Ravnskov S., Larsen J., (Eds.) - Implementation of Biocontrol in Practice in Temperate Regions - Present and Near Future. DIAS report, 119: 85-106.

Schöller M., Flinn P.W., Grieshop M.J., Zdarkova E., 2006 - Biological control of stored product pests. In: Heaps J.W., (Ed) - Insect Management for Food storage and Processing. American Association of Cereal Chemists International, St. Paul, Minnesota, USA: 67-87.

Schöller M., Prozell S., Al-Kirshi A.G., Reichmuth Ch., 1997 - Towards biological control as a major component of integrated pest management in stored product protection. Journal of Stored Products Research, 33: 81-97. 
Steidle J.L.M., Gantert C., Noldt U., Prozell S., Schöller M., 2007 - Bekämpfung von holzzerstörenden Käfern durch Massenfreilassungen der Lagererzwespe: Fiktion und Fakten: 163-172. In: Noldt U., Michels H., (Eds.) Holzschädlinge im Fokus. Alternative Maßnahmen zur Erhaltung historischer Gebäude. Schriften des LWL-Freilichtmuseums Detmold, Westfälisches Landesmuseum für Volkskunde, vol. 27, Detmold.

Wilamowski A., Kessler I., Rabin I., Prozell S., Navarro S., 2008 - Biological control of Anobium punctatum in infested books, using the parasitoid Lariophagus distinguendus. Ninth International Conference on NDT of Art, Jerusalem Israel, 25-30 May 2008.

WUdTKE A., 2002 - Möglichkeiten des Methodentransfers vom Vorratsschutz zum MaterialschutzBekämpfung von Museumsschädlingen am Beispiel der Kleidermotte Tineola bisselliella (HUM. 1823), Lepidoptera: Tineidae. Dissertation, Humboldt-Universität Berlin.

Zimmermann O., Schöller M., Prozell S., 2003 - The use of Apanteles carpatus (Hymenoptera: Braconidae) and Trichogramma spp. (Hymenoptera: Trichogrammatidae) for biological control of tineid moths (Lepidoptera). In: Credland P.F., Armitage D.M., Bell C.H., Cogan P.M., Highley E., (Eds) - Advances in Stored Product Protection. Proceedings of the $8^{\text {th }}$ International Working Conference on Stored Product Protection, 22. July 2002, York, 319321.

Zimmermann O., 2004 - Der Einsatz von Trichograma-Schlupfwespen in Deutschland. Zum aktuellen Stand der Forschung und Nutzung von Eiparasitoiden gegen Schadlepidopteren im biologischen Pflanzen- und Vorratsschutz. Gesunde Pflanzen, 56: 157-166.

ZiMMERMANN O., 2005 - Untersuchungen zur biologischen Bekämpfung der Kleidermotte Tineola bisselliella (Hummel 1823) und anderer tineider Textilschädlinge (Lepidoptera: Tineidae) mit parasitoiden Hymenopteren. Dissertation, Johannes Gutenberg-Universität zu Mainz.

Pascal Querner, University of Natural Resources and Applied Life Sciences, Department of Integrated Biology and Biodiversity Research, Group, Institute of Zoology, Gregor-MendelStraße 33, A-1180 Vienna, Austria.

E-mail: pascal.querner@boku.ac.at

Stephan Biebl, Mariabrunnweg 15, D-83671 Benediktbeuern, Germany.

E-mail: info@holzwurmfluesterer.de 